\title{
Isolation and characterization of an acid and metal tolerant Enterobacter cloacae NZS strain from former mining lake in Selangor, Malaysia
}

Nur Zurith Syafiqa Mazalan 1,2, Ayokunmi Oyeleye ${ }^{1,2}$, Raja Noor Zaliha Raja Abd. Rahman ${ }^{1,3}$, Ahmad Zaharin Aris ${ }^{4}$, Abu Bakar Salleh ${ }^{1}$ and Yahaya M. Normi ${ }^{1,2^{*}}$ (i)

\begin{abstract}
Background: Metal polluted environments have been found to harbor acid and metal tolerant bacterial communities. Metal oxidizing bacteria in particular are industrially important microorganisms that can be utilized for potential applications in biomining and bioremediation. However, some well-characterized strains are not readily culturable as they are obligate and fastidious chemolithotrophs requiring special techniques for their cultivation. Hence, this study was aimed at isolating, identifying, and characterizing indigenous metal tolerant heterotroph(s) from abandoned mines that can potentially be used for biomining or bioremediation processes in the future.

Results: Seventeen bacteria from former mining lakes were isolated and identified using 165 rRNA. Minimal inhibition concentration (MIC) and growth study of isolated bacteria carried out in Luria-Bertani media containing three different metals ions, zinc (II), copper (II), and iron (II), showed that a particular isolate termed Enterobacter cloacae NZS was found to exhibit better growth and tolerance for copper (up to $90 \mathrm{mM}$ ), zinc (up to $200 \mathrm{mM}$ ), and iron (up to $170 \mathrm{mM}$ ). Growth of the strain was notably well in the presence of iron (II). Compared to all the isolates, only E. cloacae NZS was able to be enumerated at $\mathrm{pH}$ lower than 5 while other strains were culturable only at $\mathrm{pH} 7$. Its capability in iron (II) oxidation was preliminary assessed based on the $\mathrm{pH}$, cell count, glucose consumption, and amount of iron oxidized throughout incubation in 9K media. E. cloacae NZS strain was found to be capable of oxidizing iron (II) supplied in 9K media to iron (III).

Conclusion: As preliminary investigation showed that E. cloacae NZS was able to oxidize iron (II) in 9K media at $\mathrm{pH} 2$, further optimization on the strain, medium, and culture conditions in future may be able to provide a better insight on this strain to be possibly used as an iron oxidizer for various applications.
\end{abstract}

Keywords: Enterobacter cloacae NZS, Metal ions, Metal tolerant, Iron oxidation

\footnotetext{
* Correspondence: normi_yahaya@upm.edu.my

${ }^{1}$ Enzyme and Microbial Technology Research Center, Faculty of

Biotechnology and Biomolecular Sciences, 43400 Serdang, Selangor, Malaysia

${ }^{2}$ Department of Cell and Molecular Biology, Faculty of Biotechnology and

Biomolecular Sciences, Universiti Putra Malaysia, 43400 Serdang, Selangor,

Malaysia

Full list of author information is available at the end of the article
}

\section{Springer Open}

(c) The Author(s). 2020 Open Access This article is licensed under a Creative Commons Attribution 4.0 International License, which permits use, sharing, adaptation, distribution and reproduction in any medium or format, as long as you give appropriate credit to the original author(s) and the source, provide a link to the Creative Commons licence, and indicate if changes were made. The images or other third party material in this article are included in the article's Creative Commons licence, unless indicated otherwise in a credit line to the material. If material is not included in the article's Creative Commons licence and your intended use is not permitted by statutory regulation or exceeds the permitted use, you will need to obtain permission directly from the copyright holder. To view a copy of this licence, visit http://creativecommons.org/licenses/by/4.0/. 


\section{Background}

Metal oxidizing bacteria are industrially important microorganisms for applications such as biomining and bioremediation. Biomining which involves the extraction of metals from their ores [1] with the use of bacteria is well established as an alternative to conventional physical and chemical methods [2-4]. The efficiency of metal oxidizing bacteria in the bioremediation of metal polluted sites [5-7] such as those exposed to activities like mining [8], power generation [9], electroplating, and metal processing [10] is gaining wide acceptance. These sites are enriched with huge deposits of metals. When excessively discharged, they may find their way into the food chain, posing significant health and environmental concerns [11]. Consequently, metal polluted environments have been found to harbor acid and metal tolerant bacterial communities such as acidophilic iron (II) and sulfur-oxidizing bacteria which are being harnessed for the management and bioremediation of polluted sites [12]. These special bacterial species are capable of leaching metals including copper, iron, nickel, and zinc by the dissolution of sulfide minerals such as pyrite (an important iron source in acidic environments) $[1,13]$.

Metal/iron oxidizing bacteria have been mostly characterized as acidophilic, neutrophilic, or nitrate dependent autotrophic Proteobacteria, and they include species such as the widely studied Acidithiobacillus ferrooxidans [14]. There is a dearth of information on the metabolic potential and ecological functions of indigenous, heterotrophic, and culturable iron oxidizing bacteria [15]. These heterotrophs may play significant roles in the biogeochemical recycling of various metals, and there are evidences that they may enhance the activities of metal oxidizing, acidophilic groups by an indirect mechanism. For instance, Acidiphilium acidophilum when in mixed cultures with At. ferrooxidans was reported to speed up the initial rate of ferrous iron oxidation in aerobic conditions in the presence of glucose better than the pure cultures of At. ferrooxidans [16]. In a bioleaching experiment, the heterotrophs Pseudomonas aeruginosa PAO1 and the metal tolerant Cupriavidus metallidurans $\mathrm{CH} 34$ were found to interact through biofilm formation with the autotrophic iron oxidizing Acidithiobacillus, contributing to its survivability during co-cultivation [15]. Such bacteria species therefore are easier to cultivate and may be included in the consortium of bacteria species used in biomining and bioremediation. In addition to their ability to enhance iron oxidation, these organisms can be used as ecological indicators of metal toxicity in metal polluted environments [11].

Other metal/iron oxidizing bacteria include Alicyclobacillus sp., Sulfobacillus sp. [1], At. cladus, and Leptospirillum ferriphilum [13]. However, these species are not readily culturable as they are obligate and fastidious chemolithotrophs requiring special techniques for their cultivation [17]. In addition, studies on the ecology of biomining process involving Leptospirillum sp. and Thiobacillus ferrooxidans in commercial applications have shown that not all the time are these species detected or found dominating the process [18]. This is especially the case for T. ferrooxidans [18]. This suggests the possibility that some of these known commercial species may not be able to utilize iron as expected and as such may not persist in bioreactors sufficiently enough to be directly involved in iron oxidation.

This study, therefore, was aimed at isolating, identifying, and characterizing indigenous metal tolerant heterotroph(s) from abandoned mines in Malaysia. A particular acidophile, termed Enterobacter cloacae NZS, showed the best tolerance to the concentration of metals and acidic $\mathrm{pH}$. Its ability to oxidize iron was further evaluated and hereby reported.

\section{Methods}

\subsection{Water sampling}

Water samples were obtained from three different former mining lakes located at Dataran Taman Tasik Puchong Perdana Park (3.0086 $\left.{ }^{\circ} \mathrm{N}, 101.6064^{\circ} \mathrm{E}\right)$, Paya Indah Wetlands, Dengkil $\left(2.9913737^{\circ} \mathrm{N}, 101.7167375^{\circ}\right.$ E), and Tasik Biru Seri Kundang, Kuang (3.2501292 ${ }^{\circ}$ N, $101.5235633^{\circ}$ E) in the state of Selangor, Malaysia. The water samples were placed in sterilized, capped bottles. The $\mathrm{pH}$ and temperature of these three former mining lakes were recorded.

\subsection{Isolation of bacteria from water samples}

The water samples obtained from the mining lakes were subjected to serial dilutions $\left(10^{-1}, 10^{-2}, 10^{-3}\right.$, and $\left.10^{-4}\right)$ using sterile saline water. Subsequently, the samples were inoculated onto Luria-Bertani (LB) agar, at $\mathrm{pH} 4$ and 7 respectively and subsequently incubated for $48 \mathrm{~h}$ at $37{ }^{\circ} \mathrm{C}$. Colonies with different morphological appearances were selected from the plates and further subcultured onto fresh plates to acquire individual microbial strains. Later, each bacterial isolate was cultivated in 10 $\mathrm{mL} \mathrm{LB}$ broth at $37{ }^{\circ} \mathrm{C}$ before aliquoting them in several sterile $1.5 \mathrm{~mL}$ microcentrifuge tubes containing $80 \%$ (v/ v) of glycerol for preservation at $-80^{\circ} \mathrm{C}$.

\subsection{Identification of bacterial colony and cell morphology}

Colony morphology and characteristics such as shape, color, edge, elevation, and colony surface of each bacterial isolate were visually observed and recorded. Subsequently, all bacterial samples were subjected to Gram staining for further observation of their cellular morphology under light microscope. 
2.4 Identification of bacteria using 16S rRNA sequence Firstly, each bacterial isolate was cultured in LB broth for $18 \mathrm{~h}$ at $37{ }^{\circ} \mathrm{C}$ with agitation at a speed of $230 \mathrm{rpm}$. Following this, cells were obtained via centrifugation at $14,000 \mathrm{rpm}$ for $2 \mathrm{~min}$. The genomic DNA of each bacterial sample was obtained using Wizard ${ }^{\circ}$ Genome DNA Purification Kit (Promega), based on the protocols outlined by the manufacturer. The extracted genomic DNA samples were then used as the templates for amplification of $16 \mathrm{~S}$ rRNA by polymerase chain reaction (PCR). The PCR reaction mixtures $(20 \mu \mathrm{L})$ [consisting of $1 \mu \mathrm{g}$ of bacterial genomic DNA, $1 \times$ PCR buffer, $0.25 \mathrm{mM}$ dNTPs, $2.5 \mu \mathrm{M}$ forward 8F primer (5'-AGAGTTTGATCCTGGCTCAG$3^{\prime}$ ) and U1492R reverse primer (5'-GGTTACCTTGTTAC GACTT-3'), $2.0 \mu \mathrm{M} \mathrm{MgCl}, 1.25$ unit Taq DNA polymerase] were prepared for the amplification. The following PCR profile was used: denaturation at $95{ }^{\circ} \mathrm{C}$ for $2 \mathrm{~min}, 30$ cycles of denaturation at $95{ }^{\circ} \mathrm{C}$ for $30 \mathrm{~s}$, annealing at $56{ }^{\circ} \mathrm{C}$ for $30 \mathrm{~s}$ and extension at $72{ }^{\circ} \mathrm{C}$ for $1.5 \mathrm{~min}$, and a single final extension at $72{ }^{\circ} \mathrm{C}$ for $2 \mathrm{~min}$. The presence of amplified $16 \mathrm{~S}$ rRNA fragments was firstly viewed via electrophoresis using $1 \%(\mathrm{w} / \mathrm{v})$ agarose gel. Following this, the remaining PCR products were purified via Wizard (R) Plus SV Gel and PCR Clean-up kit (Promega) following protocols recommended by the manufacturer. The purified DNA was subsequently sent for sequencing to 1st BASE Sdn. Bhd., Malaysia. The 16S rRNA (forward and reverse) sequences obtained for all bacterial samples were consolidated and aligned using the Biology Workbench software [19] to obtain their full-length sequences. Subsequently, the full-length sequences of $16 \mathrm{~S}$ rRNA were compared against the nucleotide database at National Centre for Biotechnology Information (NCBI) using the Basic Local Alignment Search Tool (BLAST) algorithm for nucleotides (BLASTN) [20] to identify the bacterial isolates.

\subsection{Screening of metal-tolerant bacteria via minimal inhibitory concentration (MIC) of metals}

The MIC for each isolated bacterial strain towards metals was carried out by using three different metals which were zinc (II) chloride, copper (II) sulfate, and iron (II) sulfate. To determine whether the isolates are able to resist high concentration of metal ions, the minimal metal concentration for each metal ions needed to inhibit the growth of the isolates was determined. For this purpose, all isolates were inoculated into respective $10 \mathrm{~mL}$ LB broth until standard cell density of 0.5 based on McFarland standard was achieved. Five milliliters of each isolate was transferred as inoculum into $0-200 \mathrm{mM}$ concentrations (at the increment of $20 \mathrm{mM}$ ) of zinc (II) chloride, copper (II) sulfate, and iron (II) sulfate. LB broth which contained isolated inoculum without the presence of metal ions was used as bacterial growth (biotic) control while LB broth which contained metal ions without isolate inoculum was used as the abiotic control. All samples were cultivated at $37^{\circ} \mathrm{C}$ for $24 \mathrm{~h}$ with $200 \mathrm{rpm}$ agitation. After cultivation, all cultures were subjected to serial dilution and subsequently plated onto the LB agar plates. All LB agar plates were incubated at $37^{\circ} \mathrm{C}$ for $24 \mathrm{~h}$ before the colony forming unit $(\mathrm{CFU} / \mathrm{mL})$ was carried out and recorded. Based on the results of this study, the isolates which showed tolerance to high metal ion concentrations were selected for further analyses.

\subsection{Effect of metal ions on E. cloacae NZS in LB media}

To investigate the possible effects of metal ions on the growth of the selected metal-tolerant bacteria, a study involving larger volume of culture $(100 \mathrm{~mL})$ was performed. The isolate which showed the highest tolerance towards three different metal ions in MIC screening process above was selected for this study. Ten milliliters of the selected isolate culture was prepared based on 0.5 McFarland standard and subsequently cultivated in 100 $\mathrm{mL} \mathrm{LB}$ culture with the presence of $1-3 \mathrm{mM}$ of metals (zinc (II) chloride, copper (II) sulfate, and iron (II) sulfate). These concentrations were chosen as initial indicator for the strain to be used for iron (II) oxidation in minimal 9K media later, without causing much adversary effect on the growth of the strain. Growth of the strain was monitored based on CFU count for every $1 \mathrm{~h}$ of cultivation. Growth rate and lag period of the bacterial strain in the presence of metal ions were determined.

\subsection{Initial pH optimization of $9 \mathrm{~K}$ media}

The optimum $\mathrm{pH}$ for the growth of the isolate in $9 \mathrm{~K}$ media [21] was obtained as described briefly. 9K media $(100 \mathrm{~mL})$ containing $3 \mathrm{~g}$ ammonium sulfate $\mathrm{L}^{-1}, 0.5 \mathrm{~g}$ dipotassium phosphate $\mathrm{L}^{-1}, 0.5 \mathrm{~g}$ magnesium sulfate heptahydrate $\mathrm{L}^{-1}, 0.1 \mathrm{~g}$ potassium chloride $\mathrm{L}^{-1}, 0.01 \mathrm{~g}$ calcium nitrate $\mathrm{L}^{-1}, 5 \mathrm{~g}$ glucose $\mathrm{L}^{-1}$, and $3.00 \mathrm{~g}$ iron sulfate heptahydrate $\mathrm{L}^{-1}$ was adjusted to $\mathrm{pH} 1,2,3$, and 4 respectively by using $1 \mathrm{~N}$ sulfuric acid. Abiotic and biotic controls were supplied in each $9 \mathrm{~K}$ media of the respective $\mathrm{pH}$ above. All cultures were cultivated at $30{ }^{\circ} \mathrm{C}$ and 200 $\mathrm{rpm}$ for 5 days. Every $24 \mathrm{~h}, 2 \mathrm{~mL}$ of the culture was obtained for $\mathrm{pH}$ measurement and $\mathrm{CFU} / \mathrm{mL}$ counting. The optimum $\mathrm{pH}$ obtained from the optimization experiment carried out above was used for subsequent studies.

\subsection{Oxidation of iron (II) to iron (III) by E. cloacae NZS}

The iron oxidizing potential of the isolate was determined using two different compositions of $9 \mathrm{~K}$ media as follows: Solution (1) containing $3.00 \mathrm{~g}$ ammonium sulfate $\mathrm{L}^{-1}, 0.50 \mathrm{~g}$ dipotassium phosphate $\mathrm{L}^{-1}, 0.50 \mathrm{~g}$ magnesium sulfate heptahydrate $\mathrm{L}^{-1}, 0.10 \mathrm{~g}$ potassium chloride $\mathrm{L}^{-1}, 0.01 \mathrm{~g}$ calcium nitrate $\mathrm{L}^{-1}, 5.00 \mathrm{~g}$ glucose $\mathrm{L}^{-1}$, and all substances were solubilized in $700 \mathrm{~mL}$ of distilled water and $\mathrm{pH}$ adjusted to 1.8 by using $1 \mathrm{~N}$ sulfuric 
acid. This solution was autoclaved at $121^{\circ} \mathrm{C}$ for $15 \mathrm{~min}$. Solution (2) was prepared by mixing homogenously 3.00 $\mathrm{g}$ of iron sulfate heptahydrate $\mathrm{L}^{-1}(10 \mathrm{mM})$ with $300 \mathrm{~mL}$ of distilled water and $\mathrm{pH}$ adjusted to 1.8 by using $1 \mathrm{~N}$ sulfuric acid. It was subsequently filter-sterilized using sterile $0.2 \mu \mathrm{m}$ cellulose acetate membrane filter prior to mixing it with $700 \mathrm{~mL}$ of solution 1 to give forth $1 \mathrm{~L}$ of sterile $9 \mathrm{~K}$ media containing $10 \mathrm{mM}$ of iron sulfate heptahydrate with $\mathrm{pH}$ adjusted to 1.8 .

For iron oxidation studies, the isolate was cultivated in $50 \mathrm{~mL} \mathrm{LB}$ broth at $37{ }^{\circ} \mathrm{C}$ until its optical density at $600 \mathrm{~nm}$ reached 1.0. Then, $15 \mathrm{~mL}$ of the bacterial culture was transferred to $85 \mathrm{~mL}$ of sterile $9 \mathrm{~K}$ media above which was supplemented with $10 \mathrm{mM}$ of ferrous ion and $0.5 \%(\mathrm{w} / \mathrm{v})$ of glucose. The culture was cultivated at $30{ }^{\circ} \mathrm{C}$ and 200 rpm for 6 days. Every $24 \mathrm{~h}, 2.5 \mathrm{~mL}$ of the culture was extracted for analysis with regards to CFU count (using serial dilution of $\left.10^{-1}-10^{-4}\right), \mathrm{pH}$, and glucose and iron (III) concentration. $\mathrm{pH}$ was measured by using $\mathrm{pH}$ meter. Iron Colourimetric Assay (Ferrozine assay) kit (Brand: BioVision K 390-100) was used to quantify iron (III) concentration, and dinitrosalicylic acid (DNS) assay was performed to measure reducing sugar (glucose) concentration.

\section{Results}

\subsection{Isolation and identification of bacterial isolates from}

\section{water sample}

Water samples obtained from the former mining lakes recorded acidic $\mathrm{pH}$ of 5 and water temperature of $30-36{ }^{\circ} \mathrm{C}$. In total, 17 bacterial samples were isolated from three different former mining lakes. On LB agar at $\mathrm{pH} 4$, only one bacterial sample termed $\mathrm{C} 1$ Acid was isolated. The remaining 16 bacterial isolates were obtained from LB agar at $\mathrm{pH}$ 7. The morphology of colonies observed for 15 of the bacterial strains was mainly circular, entire with smooth elevation and convex surface. Three of the 15 were pigmented with 2 appearing as green and 1 as yellow. Gram staining of the isolates further revealed that all isolates were Gram negative and rod shaped. Only two of all 17 isolates were coccobacilli; one of which was violet in color as observed morphologically.

The 16S rRNA fragments of all bacterial isolates were successfully amplified (Fig. 1), purified, and sequenced. Table 1 shows BLASTN analysis of all the 16S rRNA sequences of each bacterial isolate with the highest similarity. Five isolates labeled 1, B1, SS, C1, C1 Acid and 7 were found to be related to Enterobacter sp., and they were obtained from all three different former mining lakes. Isolate C1 Acid was found to be identical to E. cloacae. The green pigmented isolates, namely, Isolates 2 and 3 were closely related to Pseudomonas sp. The yellow pigmented isolate (C3 OSS) identified as Chromobacterium sp. Isolates C1 Blue with a violet color and C1 Blue 2, a non-pigmented isolate, were identified as Chromobacterium species. The remaining 6 isolates were identified to be Stenotrophomonas (A1 LY), Raoultella (Isolates 4 and 5), Achromobacter (Isolate 6), Delftia (A3SWS), Cupriavidus (C3 SD), and Klebsiella (C1 Blue 3), respectively. Based on these results, all isolates were identified as members of the phylum Proteobacteria, belonging to classes Gamma and Beta.

\subsection{Tolerance of isolated bacteria to metals}

The tolerance level of the bacteria isolates towards various metal ions was investigated by analyzing the minimum inhibitory concentration (MIC). The MIC of 17 bacterial isolates towards three different metals zinc (II), copper (II), and iron (II) is presented in Table 2. Based on the findings in Table 2, the orders of metal toxicity of most of the isolates are copper $>$ iron $>$ zinc. Copper was found to be the most toxic to the bacterial isolates

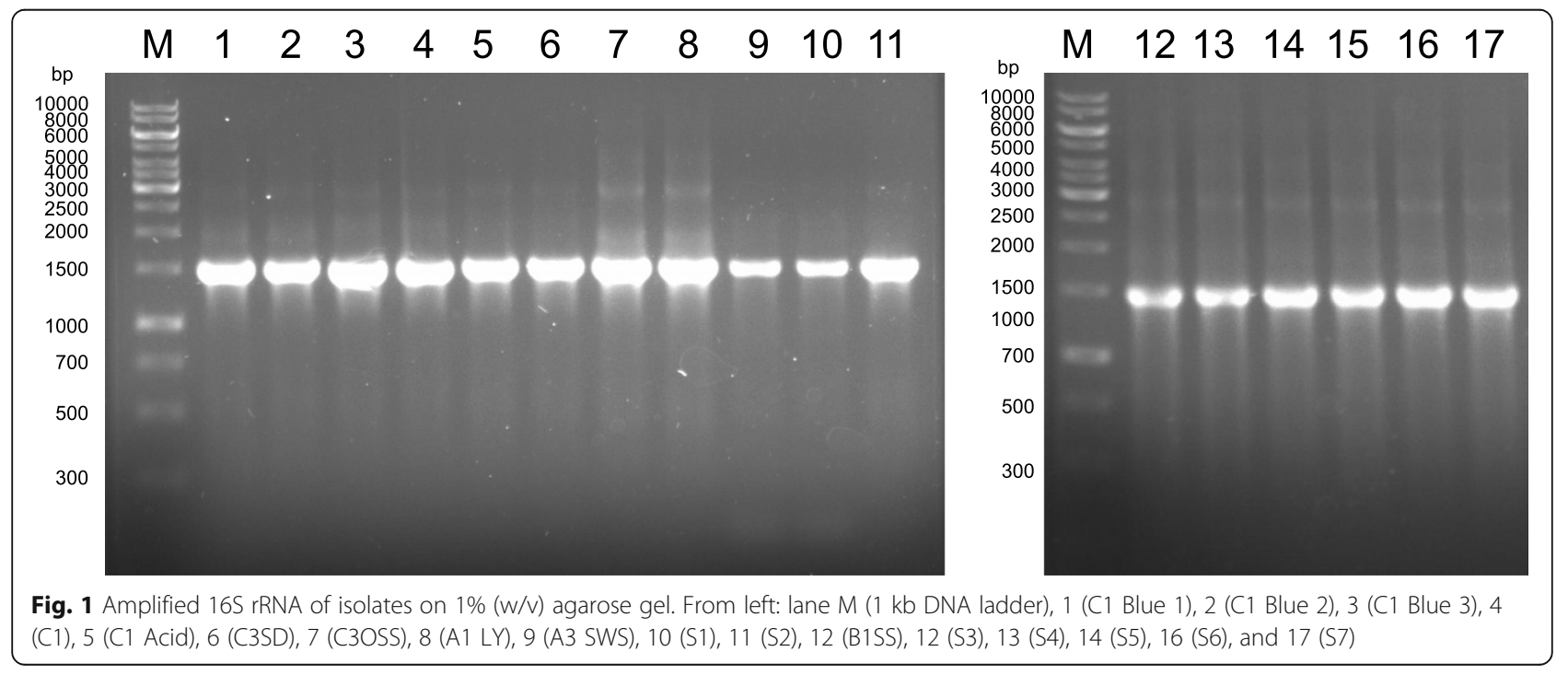


Table 1 Identity of bacterial isolates based on BLASTN results of their 165 rDNA sequences

\begin{tabular}{|c|c|c|c|c|c|c|c|c|}
\hline Sampling site & Isolate & Description of the strain & $\begin{array}{l}\text { Maximum } \\
\text { score }\end{array}$ & $\begin{array}{l}\text { Total } \\
\text { score } \\
\end{array}$ & Query cover (\%) & Evalue & Maximum identity (\%) & Accession \\
\hline \multirow{5}{*}{$\begin{array}{l}\text { Dataran Taman Tasik } \\
\text { Puchong Perdana Park, } \\
\text { Puchong }\end{array}$} & Isolate 1 & Enterobacter cloacae & 261 & 261 & 100 & $1 e-66$ & 100 & KJ588203.1 \\
\hline & A1LY & Stenotrophomonas maltophilia & 1507 & 1507 & 100 & 0.0 & 100 & JX394033.1 \\
\hline & Isolate 2 & Pseudomonas aeruginosa & 388 & 388 & 100 & $7 e-105$ & 100 & KC479131.1 \\
\hline & Isolate 3 & Pseudomonas aeruginosa & 935 & 935 & 100 & 0.0 & 100 & KF583972.1 \\
\hline & A3SWS & Delftia tsuruhatensis & 1844 & 2578 & 96 & 0.0 & 100 & JF309186.1 \\
\hline \multirow{4}{*}{$\begin{array}{l}\text { Paya Indah Wetlands, } \\
\text { Dengkil }\end{array}$} & B1SS & Enterobacter asburiae & 42.1 & 42.1 & 100 & 0.025 & 100 & KJ588198.1 \\
\hline & Isolate 4 & Raoultella ornithinolytica & 1046 & 1046 & 100 & 0.0 & 100 & KF358448.1 \\
\hline & Isolate 5 & Raoultella ornithinolytica & 1177 & 1177 & 100 & 0.0 & 100 & KF358448.1 \\
\hline & Isolate 6 & Achromobacter sp. & 998 & 998 & 100 & 0.0 & 100 & JQ794626.1 \\
\hline \multirow{8}{*}{$\begin{array}{l}\text { Tasik Biru Seri Kundang, } \\
\text { Kuang }\end{array}$} & $\mathrm{C} 1$ & Enterobacter cloacae & 1221 & 1221 & 100 & 0.0 & 100 & KC702725.1 \\
\hline & C1 Acid & Enterobacter cloacae & 1221 & 1221 & 100 & 0.0 & 100 & KC702725.1 \\
\hline & C3 OSS & Chryseobacterium sp. & 1068 & 1068 & 100 & 0.0 & 100 & $J N 545042.1$ \\
\hline & C3SD & Cupriavidus sp. & 1474 & 1474 & 100 & 0.0 & 100 & JX093175.1 \\
\hline & Isolate 7 & Enterobacter hormaechei & 424 & 424 & 100 & $2 e-115$ & 100 & KF551982.1 \\
\hline & C1 Blue1 & Chromobacterium violaceum & 320 & 320 & 100 & $3 e-84$ & 100 & KF819714.1 \\
\hline & C1 Blue 2 & Chromobacterium sp. & 464 & 464 & 100 & $2 e-127$ & 100 & KF137653.1 \\
\hline & C1 Blue 3 & Klebsiella oxytoca & 1003 & 1003 & 100 & 0.0 & 100 & JX530854.1 \\
\hline
\end{tabular}

followed by iron, and then zinc was least toxic. Isolates $\mathrm{C} 1$ and $\mathrm{C} 1$ Acid tolerated the highest concentrations of copper (II) with an MIC of $90 \mathrm{mM}$, followed by Isolate 1 and C3 OSS with an MIC of $30 \mathrm{mM}$. Other isolates could not tolerate even up to $10 \mathrm{mM}$ of copper. With respect to iron (II) and zinc (II), the highest MICs reaching up to 200 and $170 \mathrm{mM}$ were also observed with Isolates $\mathrm{C} 1$ Acid and $\mathrm{C} 1$ (both identified as E. cloacae). From here onwards, $\mathrm{C} 1$ Acid was designated as E. cloacae NZS and was used for further characterizations.

Table 2 Screening of metal tolerant bacterial isolates through their minimal inhibition concentration (MIC) in LB media containing 3 different metals

\begin{tabular}{|c|c|c|c|c|}
\hline \multirow[t]{2}{*}{ Isolate } & \multirow[t]{2}{*}{ Identified genus and species } & \multicolumn{3}{|c|}{ MIC of isolates towards } \\
\hline & & Zinc (II) (mM) & Iron (II) (mM) & Copper (II) (mM) \\
\hline Isolate 1 & Enterobacter sp. & 90 & 10 & 30 \\
\hline A1LY & Stenotrophomonas maltophilia & 90 & 60 & 20 \\
\hline Isolate 2 & Pseudomonas aeruginosa & 200 & 200 & $<10$ \\
\hline Isolate 3 & Pseudomonas aeruginosa & 200 & 200 & $<10$ \\
\hline A3SWS & Delftia tsuruhatensis & 30 & 10 & $<10$ \\
\hline B1SS & Enterobacter asburiae & 90 & 30 & 10 \\
\hline Isolate 4 & Raoultella ornithinolytica & 60 & 40 & 10 \\
\hline Isolate 5 & Raoultella ornithinolytica & 60 & 40 & 10 \\
\hline Isolate 6 & Achromobacter sp. & 70 & 10 & 10 \\
\hline C1 & Enterobacter cloacae & 200 & 170 & 90 \\
\hline C1 Acid & Enterobacter cloacae NZS & 200 & 170 & 90 \\
\hline C3 OSS & Chryseobacterium sp. & 30 & $<10$ & 30 \\
\hline C3SD & Cupriavidus sp. & 80 & 10 & $<10$ \\
\hline Isolate 7 & Enterobacter hormaechei & 90 & 130 & $<10$ \\
\hline C1 Blue 1 & Chromobacterium violaceum & 80 & 100 & $<10$ \\
\hline C1 Blue 2 & Chromobacterium sp. & 30 & 10 & $<10$ \\
\hline C1 Blue 3 & Klebsiella sp. & 70 & 10 & $<10$ \\
\hline
\end{tabular}


3.3 Growth study of metal tolerant isolate in the presence of metals

A growth study of E. cloacae NZS in the presence of metal ions was performed using $100 \mathrm{~mL}$ LB broth supplemented with different concentrations of zinc
(II), copper (II), and iron (II). Based on the results in Fig. $2 \mathrm{a}-\mathrm{c}$, overall, in the presence of the metals tested, no drastic or significant reduction in CFU of the bacterium was observed with the exception when there was 2 and $3 \mathrm{mM}$ of zinc (II) chloride in the

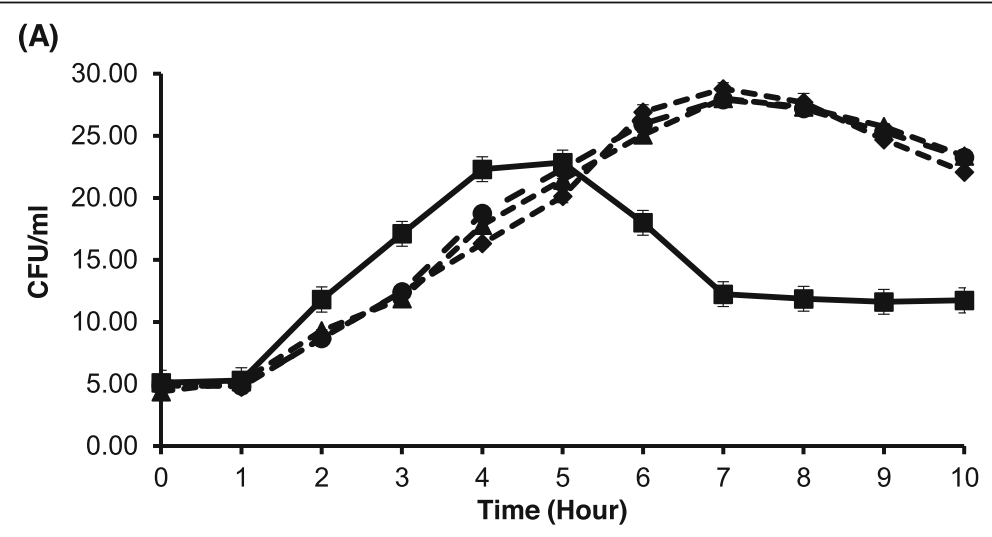

(B)

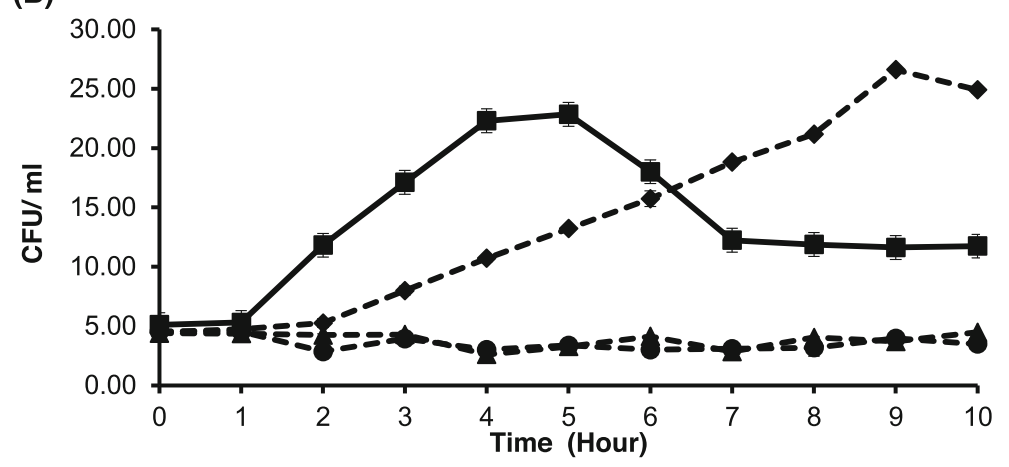

(C)

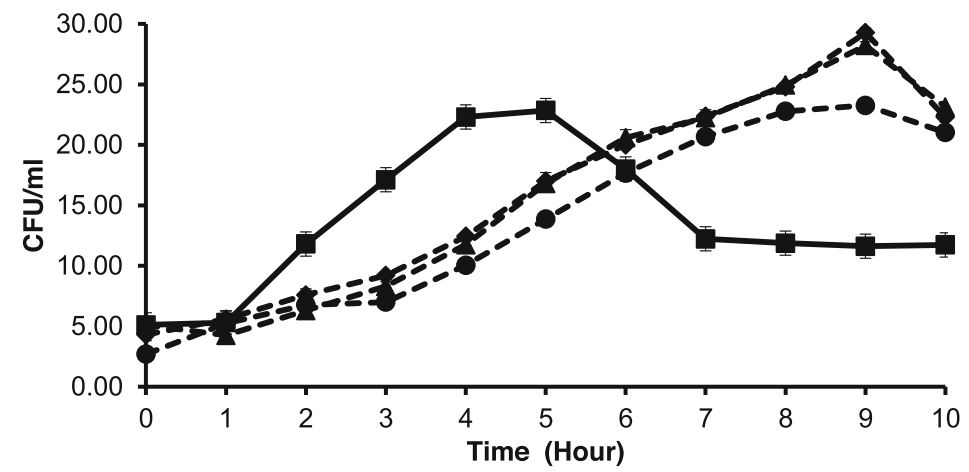

$\rightarrow-$ Biotic control (E. cloacae NZS culture without metal present)

- E. cloacae NZS culture with $1 \mathrm{mM}$ metal present

--A-. E. cloacae NZS culture with $2 \mathrm{mM}$ metal present

-- - E. cloacae NZS culture with $3 \mathrm{mM}$ metal present

Fig. 2 Growth study of E. cloacae NZS with $0-3 \mathrm{mM}$ of a iron (II), b zinc (II), and c copper (II). Cells were cultivated at $37^{\circ} \mathrm{C}$ with agitation of $200 \mathrm{rpm}$ 
media. In fact, the presence of metals seemed to have promoted its growth compared to the control, and by the 9th hour of the cultivation period, all cultures which contained metals in the media recorded higher CFUs compared to the control (with the exception for those with 2 and $3 \mathrm{mM}$ of zinc (II) chloride present in the media) [Fig. $2 \mathrm{a}-\mathrm{c}$ ].

The growth curve data in Fig. 2a-c suggests that the log phase of E. cloacae NZS in the presence of $1 \mathrm{mM}$ of zinc (II) chloride and 1-2 $\mathrm{mM}$ of copper (II) sulfate was delayed, and not as distinct and as comparable to that of their controls (Fig. 2 b and c). In contrast to this, the log phase of the bacteria in the presence of $1-3 \mathrm{mM}$ of iron (II) sulfate was not delayed and was distinct and comparable to that of its control (Fig. 2a). In fact, it entered its exponential phase in less than $2 \mathrm{~h}$ of cultivation. The CFU of the bacteria during its log phase in the 3rd hour of cultivation in $1-3 \mathrm{mM}$ of iron (II) sulfate was 1.5 times higher than in $1 \mathrm{mM}$ of zinc (II) sulfate and 1.3 times higher than in $1 \mathrm{mM}$ of copper (II) sulfate (Fig. 2a-c).

\subsection{Optimization of initial $\mathrm{pH}$ of $9 \mathrm{~K}$ media}

A preliminary study was carried out to identify the suitable initial $\mathrm{pH}(1-4)$ at which iron oxidation is best supported by $E$. cloacae NZS when grown in $9 \mathrm{~K}$ media with minimal formation of jarosite ( $\mathrm{Fe}^{3+}$ hydroxysulfates). Jarosite is formed from continuous reactions of hydrogen ion consumption and ferric ion hydrolysis during iron oxidation process. Subsequently, it will combine with ammonium ion in $9 \mathrm{~K}$ media to produce ammoniojarosites [22]. Several studies have suggested adjustments of the initial $\mathrm{pH}$ of $9 \mathrm{~K}$ media from 1.6-1.7 to minimize the formation of jarosites [22, 23].

The outcomes from the optimization of the initial $\mathrm{pH}$ of $9 \mathrm{~K}$ media showed that E. cloacae NZS was able to grow in acidic condition in $9 \mathrm{~K}$ media (Fig. $3 \mathrm{a}-\mathrm{c}$ ), even at an initial $\mathrm{pH}$ as low as 2 . This indicates that it is an acidophilic bacteria. According to Liu et al. [22], bacterial growth and activity is blocked by the acidity of $9 \mathrm{~K}$ media at $\mathrm{pH}$ below 1.5, which explained the absence of any E. cloacae NZS colonies at $\mathrm{pH} 1$. Based on the growth curves in Fig. 3a-c, the cell density of $E$. cloacae NZS recorded a decrease from 10 to $6 \mathrm{CFU} / \mathrm{mL}$ in the first day of its cultivation. However, its cell density steadily increased subsequently to $12 \mathrm{CFU} / \mathrm{mL}$. Among the $\mathrm{pH}$ tested, $\mathrm{pH} 2$ in the presence of $100 \mathrm{mM} \mathrm{FeSO}_{4}$ was able to support growth of the strain at a slightly longer period compared to the biotic control and cultures grown at $\mathrm{pH}$ 3 and 4, respectively. The sudden drop in the cell densities observed for samples cultivated at $\mathrm{pH} 3$ and 4 may be due to encrustation of cells by the formation of iron III mineral precipitates. The formation of crusts around iron II oxidizing cells may lead to impaired substrate uptake and metabolite release and eventually cell death [24]. $\mathrm{pH}$ below 2.0 appeared to be optimum for E. cloacae NZS growth, and iron metabolism as studies have shown that the formation of these crusts is not favored at such low $\mathrm{pH}$ [24]. However, iron III precipitates may form jarosites which were visible as tiny precipitates in very small amount that possibly accounts for the reduction in cell biomass observed in Fig. 4. Although the experiment recorded a low CFU after day 3, there was a continuous increase in the production of iron III. The reason for this is not clear, but there are possibilities that the proposed presence of jarosites could act as carriers [25] of viable cells which were still capable of ferrous iron oxidation. Reports have shown that microbial biomass or cells become attached to jarosites by means of exopolysaccharides or biofilms [26] hence the possibility of not being enumerated as free cells from the culture in the medium.

\subsection{Oxidation of iron (II) to iron (III) by E. cloacae NZS}

The ability of $E$. cloacae NZS in oxidizing ferrous ion to ferric ion in 9K media was investigated. Based on Fig. 4a, a typical growth curve of $E$. cloacae NZS was obtained. A lag phase was observed when the inoculum was transferred from rich LB medium to minimal salt 9K medium in days $0-1$. The drastic change in nutrient composition from a nutrient rich environment to a minimal medium may have resulted in a shock to the bacteria cells as they would have had to adapt to their new medium by synthesizing essential metabolites that are not present in the $9 \mathrm{~K}$ medium. As the strain began to adapt to the environment of the minimal media, it resumed its exponential growth, but at a slower rate by consuming the glucose provided in $9 \mathrm{~K}$ media as its carbon source until it reached stationary phase at day 3 . At day 4 , it entered death phase. Its population decreased gradually until no live colony could be observed on agar plate at day 6 .

At the early incubation [day 0 to day 1 in Fig. 4b], the $\mathrm{pH}$ of the liquid media increased from 1.8 to 2.1. This might be due to cell density and consumption of hydrogen ion during oxidation of ferrous ion [24]. By day 2 until day 6 of the cultivation process, the $\mathrm{pH}$ of the $9 \mathrm{~K}$ media decreased slightly throughout 6 days of incubation which probably indicated the formation of sulfuric acid in small quantity as oxidation process occurred. It is interesting to note that $E$. cloacae NZS carried out oxidation of ferrous ion to ferric ion since the incubation started. The final concentration of ferric ion formed was $220 \mu \mathrm{M}$ with the oxidation rate of $50 \mu \mathrm{M}$ ferric ion per day.

\section{Discussion}

Seventeen bacteria strains were isolated from three different mining lakes in Selangor state, Malaysia. The isolates were of diverse genera including Enterobacter, Pseudomonas, Stenotrophomonas, Raoultella, Achromobacter, Delftia, Cupriavidus, and Klebsiella. They were 
(A)

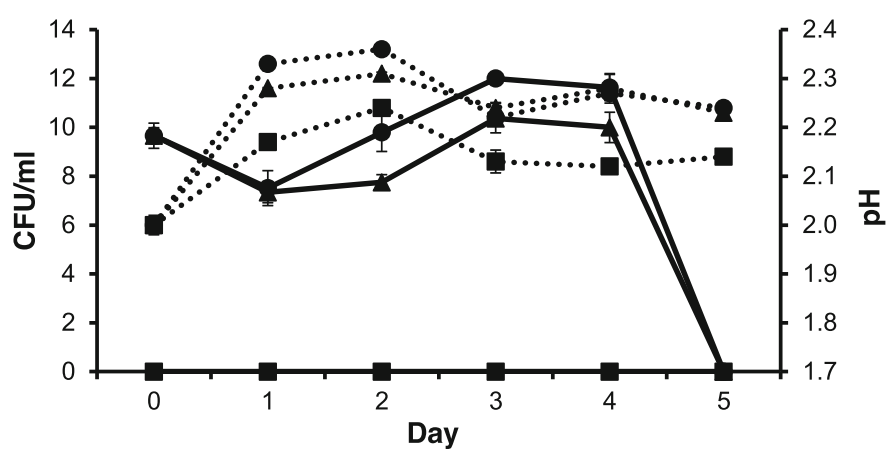

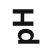

(B)

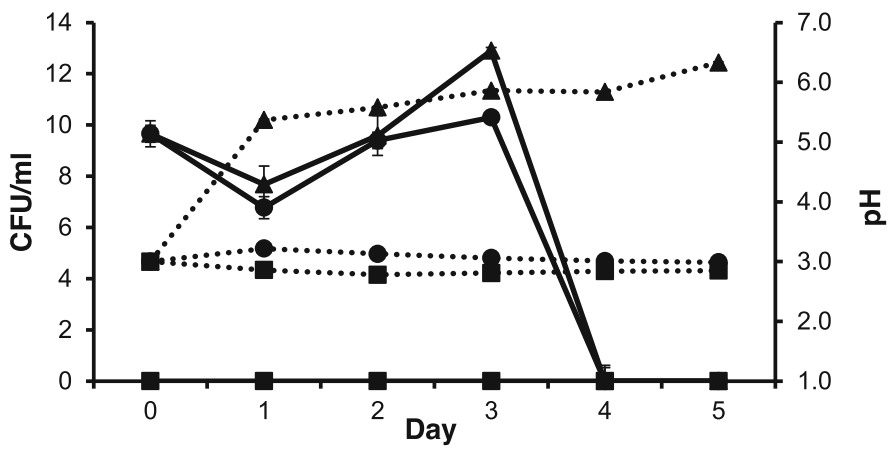

(C)

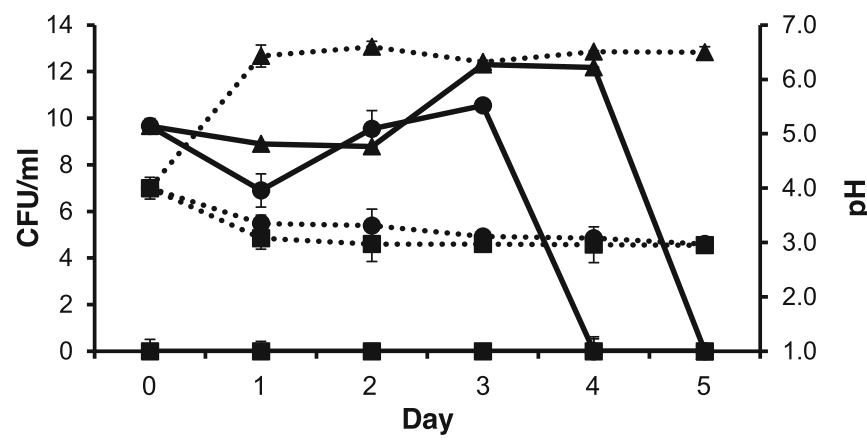

工丂

Abiotic control

(9K media with $100 \mathrm{mM} \mathrm{FeSO}_{4}$ )

$\cdots$ - $\cdot \mathrm{pH}$ of abiotic control

Biotic control (E. cloacae NZS in 9K media without $\mathrm{FeSO}_{4}$ )

E. cloacae NZS in $9 \mathrm{~K}$ media with $100 \mathrm{mM} \mathrm{FeSO}_{4}$

.... $\mathrm{pH}$ of biotic control

..-. $\mathrm{pH}$ of $E$. cloacae NZS culture with $100 \mathrm{mM} \mathrm{FeSO}_{4}$

Fig. 3 Optimization of initial pH of $9 \mathrm{~K}$ media at $\mathrm{pH}$ a 2, b 3, and $\mathbf{c} 4$. No graph was plotted for 9K media with pH 1 as no bacterial growth was observed throughout incubation period. Cells were cultivated in $9 \mathrm{~K}$ media containing $5 \mathrm{~g} / \mathrm{L}$ glucose with and without $\mathrm{FeSO}_{4}$, at $30^{\circ} \mathrm{C}$ at $200 \mathrm{rpm}$ for 5 days

also of diverse strains and forms as seen by the appearance of pigmented and non-pigmented Chromobacterium. This was not surprising as Chromobacterium species have been reported to exist as pigmented, latepigmented, and non-pigmented forms [25]. All the species isolated were found to be members of the Beta and Gamma classes of the phylum Proteobacteria, respectively. Members of this phylum especially the gamma Proteobacteria have been reported to be iron oxidizing bacteria [14].
The diversity of isolates obtained however indicates the richness of indigenous microbial communities in mining lakes. Some earlier reports have associated the rise in the diversity of bacteria community in metal polluted soils, mining lakes, or metal tailings to the rise in $\mathrm{pH}$ of such samples towards neutral [27, 28], as well as the bioavailability of copper ions and organic matter in such environments [27]. Chromobacteria, Pseudomonas, Stenotrophomonas, and Cupriavidus species are present as part of the normal microflora of soil and marine 
(A)

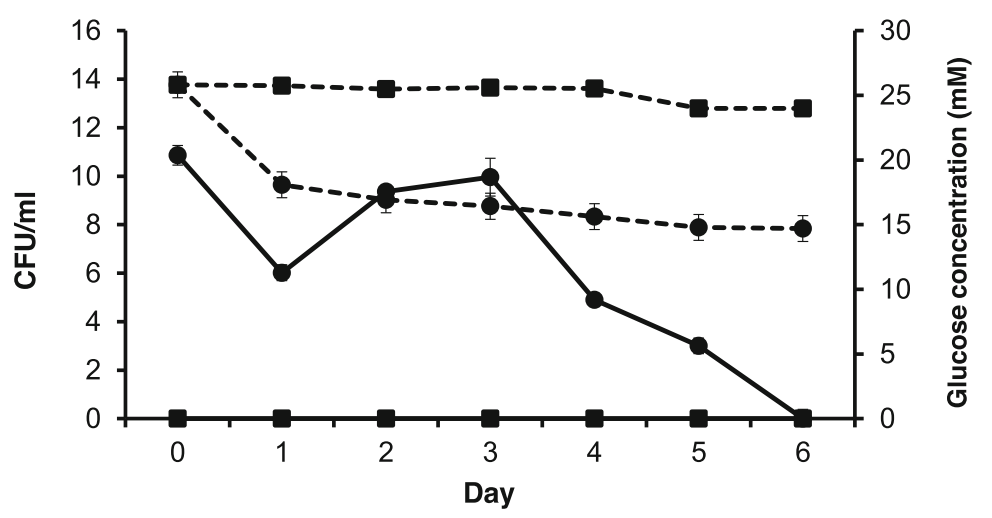

(B)
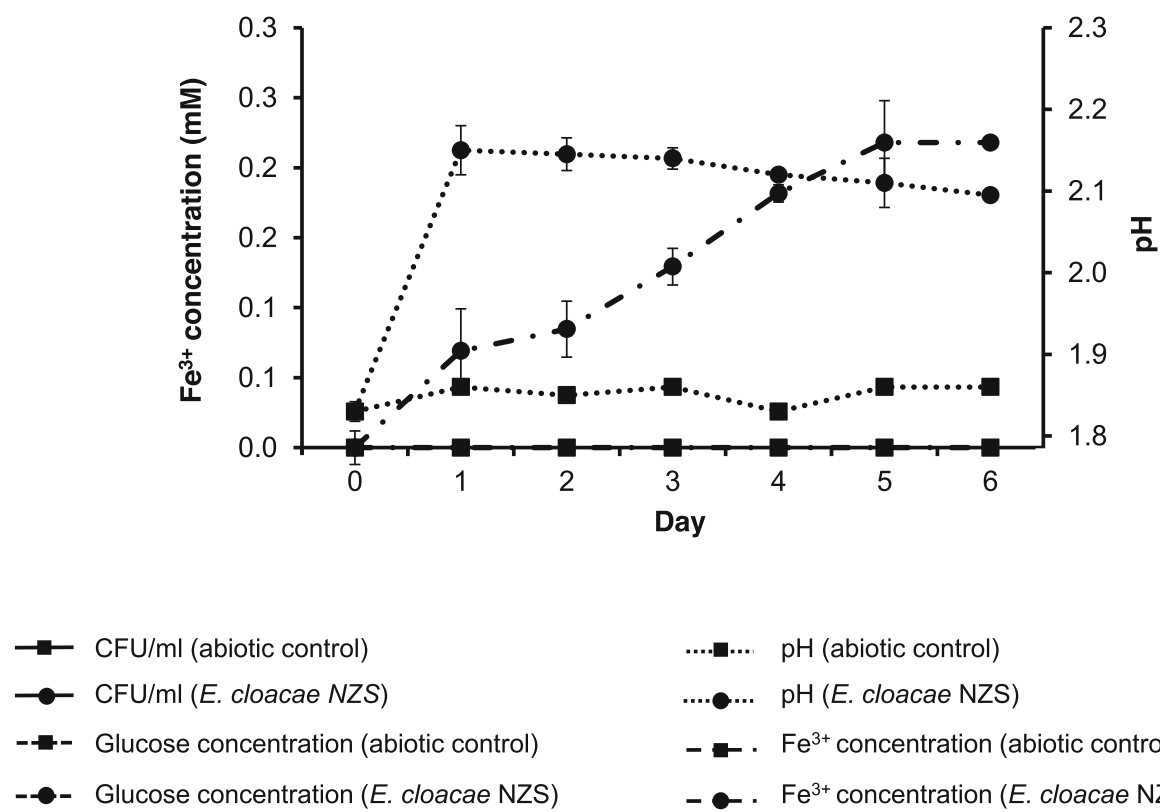

$\begin{array}{ll}\ldots . . . . & \mathrm{pH}(\text { abiotic control) } \\ \ldots . . . & \mathrm{pH}(\text { E. cloacae } \mathrm{NZS}) \\ \text { —- } & \mathrm{Fe}^{3+} \text { concentration (abiotic control) } \\ \text { - } & \mathrm{Fe}^{3+} \text { concentration (E. cloacae NZS) }\end{array}$

Fig. 4 Assessment of E. cloacae NZS in terms of $\mathbf{a}$ growth and $\mathbf{b}$ iron (III) produced during oxidation of iron (II) to iron (III) in $9 \mathrm{~K}$ media at $\mathrm{pH} 2$. Cells were cultivated at pH 2 in $9 \mathrm{~K}$ media containing $5 \mathrm{~g} / \mathrm{L}$ glucose with and without FeSO4, at $30{ }^{\circ} \mathrm{C}$ at $200 \mathrm{rpm}$ for 6 days

environments. Some species of these genera have been reported to tolerate high concentration of heavy metals. For instance, Stenotrophomonas maltofilia was resistant to high levels of toxic metals including selenite, tellurite, cadmium, lead, cobalt, zinc, silver, and mercury [29]; Cupriavidus necator reportedly showed tolerance and ability to leach cadmium, zinc, and copper from contaminated soils [30] while C. gilardii CR3 removed copper from chemical mechanical polishing (CMP) wastewater at an optimum $\mathrm{pH}$ of 5 [31]. Pseudomonas sp., strain DC-B3, was found to be resistant to copper and cadmium [32], and $P$. protegens strains (S4LiBe and S5LiBe) isolated from an agricultural well near a heavy metal polluted site were reportedly tolerant to $2.0 \mathrm{mM} \mathrm{K}_{2} \mathrm{Cr}$ O7 and $3.0 \mathrm{mM} \mathrm{CoSO}, \mathrm{HgSO}_{4}, \mathrm{CdSO}_{4} .8 \mathrm{H}_{2} \mathrm{O}$, and
$\mathrm{PbCl}_{2}$ [32]. In the same study [33], the reference strain Pseudomonas protegens strain $\mathrm{CHAO}^{\mathrm{T}}$ showed poor tolerance to mercury, cadmium, plumbum, and copper, an indication that metal tolerance could be species specific. Likewise, Raoultella sp. strains X13 [34] and SM1 [35] Delftia sp. BAs29 [36] and Delftia acidovorans [37] have all shown resistance along with metal reduction or biosorption capacity on cadmium, uranium, arsenate, and gold, respectively. In this study, however, these bacteria isolates Stenotrophomonas (A1 LY), Raoultella (Isolates 4 and 5), Achromobacter (Isolate 6), Delftia (A3SWS), and Cupriavidus (C3 SD) demonstrated very low resistance to the tested metals especially under combined acidic and metal-containing (i.e., copper, iron, and zinc) experimental conditions. This observation corresponds 
to a more recent report by Yang et al. [30], in which the biosorption and bioaccumulation of copper by $C$. gilardii CR3 was found to be $\mathrm{pH}$ dependent and was only optimum at $\mathrm{pH}$ 5. The presence of these organisms in the former mining lake, therefore, may be dependent on the moderately acidic condition and metal-rich mine at $\mathrm{pH} 5$ which well supports the growth of non-extreme acidophiles. In this study, the poor growth of isolates on exposure to high copper concentrations confirms the possible toxic effect of heavy metals on moderately acidophilic bacteria grown at low $\mathrm{pH}$. Although iron, zinc, and copper are essential elements which play significant roles in biological functions and processes, exposure to amounts in excess of what is required by macromolecules, or cells can in turn become toxic. For instance, when in excess in their "free" states, iron and copper are able to form thiolate bonds with iron-sulfur clusters or reactive oxygen species (ROS) in a Fenton/Haber-Weiss reaction cycle and disrupt leading to oxidative stress in cells, as well as protein and DNA damage [38-41]. Similarly, zinc exists as a divalent metal and under physiological conditions plays an important role as a cofactor in many enzymes. However, it has been reported also to be toxic to bacteria at high concentrations [42].

Interestingly, both $E$. cloacae isolates designated as $E$. cloacae NZS showed better tolerance to copper (up to $90 \mathrm{mM}$ ) (Table 2). Also, they exhibited the highest tolerance with similar MIC results towards zinc (up to 200 $\mathrm{mM}$ ) and iron (up to $170 \mathrm{mM}$ ). Although E. cloacae is more known as a nosocomial pathogen [43-45], it exists as a commensal in the gut microflora and as endophytes in plants $[46,47]$. It is also frequently encountered in environmental samples such as potable water and sewage. Its ability to tolerate high concentrations of copper, zinc, and iron suggests that they might possess an advance metal homeostasis or detoxifying mechanism [39]. Heavy metal resistance in an endophytic Enterobacter sp. was reported towards plumbum, copper, and zinc in an experiment to identify plasmid-mediated metal tolerance in the species [48]. Consistent with these observations is the detection of genes that confer tolerance to heavy metals in Enterobacter sp. A draft genome sequence analysis of E. cloacae SBP-8 revealed the presence of genes encoding CopC, CopD, and $\mathrm{CueO}$ copper oxidizing proteins; ZitB for zinc transporter and efflux; $\mathrm{CzcB}$ for multiple resistance towards cobalt, zinc, and cadmium; and $A r s B C H, A r s B$, and $A r s C$ operons for resistance to arsenic [48-50].

Of all the isolates, only E. cloacae NZS was enumerated at $\mathrm{pH}$ lower than 5 compared with other strains which were culturable only at $\mathrm{pH} 7$.

The strain could multiply its population and showed better tolerance when tested with all three metals above compared to other strains-notably so in the presence of iron (II). Evaluation on its iron oxidation potential particularly in $9 \mathrm{~K}$ media containing $0.50 \%(\mathrm{w} / \mathrm{v})$ of glucose as carbon source and $10 \mathrm{mM}$ of iron sulfate heptahydrate $(3 \mathrm{~g} / \mathrm{L})$ showed that the strain was able to oxidize ferrous ion to produce approximately $220 \mu \mathrm{M}$ of ferric ion during 6 days of cultivation. In addition, its ability to grow at $\mathrm{pH} 2$ with agitation also makes it an acidophile. It is not clear as to the reason why cell growth did not increase in cultures that do not contain iron (II) beyond the third day of cultivation. As we have yet to learn more of the biological physiology and performance of the isolate, further characterizations of the isolate under various conditions and in various different media would be able to give more details into this.

Reports regarding the iron oxidizing property of E. cloacae are very scarce, and findings from this study add to the very few reports of the potential of this bacterium as an iron oxidizing agent. In one study, the ability of $E$. cloacae to oxidize iron (II) to iron (III) was observed while demonstrating the corrosion behavior of carbonsteel in the presence of E. cloacae and Gordonia sp. [51]. In a different study however, the iron oxidizing potential of E. cloacae NZS contrasts with the studies of $\mathrm{Su}$ et al. [52] and Liu and Wang [53] who reported the efficient reduction of Fe (III) by Enterobacter sp. CC76 and L6, respectively. This suggests that some Enterobacter sp. due to their facultative anaerobic nature might be capable of switching their redox potential in the iron cycle to perform one of the dual roles of reduction of ferric iron or oxidation of ferrous iron depending on the availability of oxygen [54]. Finally, E. cloacae NZS iron oxidation property at an acidic $\mathrm{pH}$ of 2 is consistent with reports from other acidophilic iron oxidizers which have been shown to have increased iron oxidizing capacity under anoxic and extreme acidic situation where iron (II) is soluble [55]. Previous reports have indicated that iron oxidizing bacteria belong to one of four groups of Proteobacterium including acidophilic, aerobic iron oxidizers; neutrophilic, aerobic iron oxidizers; neutrophilic anaerobic (nitrate-dependent) iron oxidizers; and anaerobic photosynthetic iron oxidizers $[54,56]$. Based on these findings, therefore E. cloacae NZS can be categorized as a heterotrophic, acidophilic, and aerobic ironoxidizing Proteobacteria. Further studies to investigate the effect of varying Fe II/III ratio as well as the need for nitrates and organic materials like citrate under anoxic and microoxic conditions will provide more insights into the ferrous oxidation mechanism of E. cloacae NZS.

\section{Conclusion}

Out of the seventeen isolated metal tolerant strains, one particular strain termed E. cloacae NZS was found to be tolerant to the metals tested with minimal effect to its growth. As preliminary investigation showed that it was 
able to oxidize iron (II) in $9 \mathrm{~K}$ media at $\mathrm{pH} 2$, further optimization on the strain, medium, and culture conditions can be carried out in the future to provide a better insight on this strain to be possibly used as an iron oxidizer for various applications. In addition, varying Fe II/III ratio and supply of nitrates and organic materials like citrate under anoxic and microoxic conditions will provide more insights into the ferrous oxidation mechanism of E. cloacae NZS.

\section{Abbreviations}

CFU: Colony forming unit; CFU/mL: Colony forming unit per milliliter; DNS: Dinitrosalicylic acid; LB: Luria-Bertani; MIC: Minimal inhibitory concentration; PCR: Polymerase chain reaction; rRNA: Ribosomal DNA; ROS: Reactive oxygen species; v/v: Volume per volume

\section{Acknowledgements}

This work was supported by the Graduate Research Fellowship, School of Graduate Studies, Universiti Putra Malaysia awarded to NZSM.

\section{Authors' contributions}

NZSM and YMN designed the experiments. NZSM executed the experiments. YMN and NZSM analyzed the data. ABS and RNZRAR gave input throughout the study related to microbiological analysis while AZA gave input related to metal compounds analysis. NZSM, AO, and YMN wrote, organized, and revised the manuscript. All authors have read and approved the manuscript.

\section{Funding}

This work was supported by the Graduate Research Fellowship, School of Graduate Studies, Universiti Putra Malaysia awarded to NZSM.

\section{Availability of data and materials}

All data generated or analyzed during this study are included in this published article.

\section{Ethics approval and consent to participate}

Not applicable

\section{Consent for publication}

Not applicable

\section{Competing interests}

The authors declare that they have no competing interests throughout this study.

\section{Author details}

${ }^{1}$ Enzyme and Microbial Technology Research Center, Faculty of Biotechnology and Biomolecular Sciences, 43400 Serdang, Selangor, Malaysia. ${ }^{2}$ Department of Cell and Molecular Biology, Faculty of Biotechnology and Biomolecular Sciences, Universiti Putra Malaysia, 43400 Serdang, Selangor, Malaysia. ${ }^{3}$ Department of Microbiology, Faculty of Biotechnology and Biomolecular Sciences, Universiti Putra Malaysia, 43400 Serdang, Selangor, Malaysia. ${ }^{4}$ Department of Environmental Sciences, Faculty of Environmental Studies, Universiti Putra Malaysia, 43400 Serdang, Selangor, Malaysia.

\section{Received: 7 November 2019 Accepted: 29 April 2020}

Published online: 15 July 2020

\section{References}

1. Vera M, Schippers A, Sand W (2013) Progress in bioleaching: fundamentals and mechanisms of bacterial metal sulfide oxidation-part A. Appl Microbiol Biotechnol. 97:7529-7541

2. Malik A (2004) Metal bioremediation through growing cells. Environ Int. 30: 261-278

3. Sheoran AS, Sheoran V (2006) Heavy metal removal mechanism of acid mine drainage in wetlands: a critical review. Miner Eng 19:105-116

4. Jerez CA (2017) Biomining of metals: how to access and exploit natural resource sustainably. Microb Biotechnol. 10:1191-1193
5. Lovley DR, Coates JD (1997) Bioremediation of metal contamination. Curr Opin Biotechnol. 8:285-289

6. Ojuederie O, Babalola O (2017) Microbial and plant-assisted bioremediation of heavy metal polluted environments: a review. Int J Environ Res Public Health. 14:1504

7. Kumar, V, \& Tiwari, A (2018) An efficient approach towards bioremediation of heavy metal pollution from soil and aquatic environment: an overview. A. , Gautam \& C., Pathak (Eds.). Contamination in soil Environment. 57-73. ASTR AL.

8. Navarro MC, Pérez-Sirvent C, Martínez-Sánchez MJ, Vidal J (2008) Abandoned mine sites as a source of contamination by heavy metals: a case study in a semi-arid zone. J Geochem Explor. 96:183-193

9. Roychowdhury R, Roy M, Rakshit A, Sarkar S (2018) Arsenic bioremediation by indigenous heavy metal resistant bacteria of fly ash pond. Bull Environ Contam Toxicol. 101:527-535

10. Zouboulis Al, Loukidou MX, Matis KA (2004) Biosorption of toxic metals from aqueous solutions by bacteria strains isolated from metal-polluted soils. Process Biochem. 39:909-916

11. Selvin J, Priya SS, Kiran GS, Thangavelu T (2009) Sponge-associated marine bacteria as indicators of heavy metal pollution. Microbiol Res 164:352-363

12. Baker BJ, Banfield JF (2003) Microbial communities in acid mine drainage. FEMS Microbiol Ecol. 44:139-152

13. Xiao C, Xu G, Wang Q, Chi R (2017) Biosolubilization of low-grade rock phosphate by mixed thermophilic iron-oxidizing bacteria. J Adv Oxid Technol. 20:20170023

14. Quatrini R, Johnson DB (2018) Acidithiobacillus ferrooxidans. Trends Microbiol. xx:10-11.

15. Jeremic S, Beškoski VP, Djokic L, Vasiljevic B (2016) Interactions of the metal tolerant heterotrophic microorganisms and iron oxidizing autotrophic bacteria from sulphidic mine environment during bioleaching experiments. J Environ Manage. 172:151-161

16. Marchand EA, Silverstein J (2003) The role of enhanced heterotrophic bacterial growth on iron oxidation by Acidithiobacillus ferrooxidans. Geomicrobiol J. 20:231-244

17. Johnson DB, Bridge TA (2002) Reduction of ferric iron by acidophilic heterotrophic bacteria: evidence for constitutive and inducible enzyme systems in Acidiphilium spp. J Appl Microbiol. 92:315-321

18. Rawlings DE, Tributsch H, Hansford GS (1999) Reasons why 'Leptospirillum'like species rather than Thiobacillus ferrooxidans are the dominant ironoxidizing bacteria in many commercial processes for the biooxidation of pyrite and related ores. Microbiology. 145:5-13

19. Subramaniam S (1998) The Biology Workbench - a seamless database and analysis environment for the biologist. Proteins 32(1):1-2

20. Altschul SF, Gish W, Miller W, Myers EW, Lipman DJ (1990) Basic local alignment search tool. J Mol Biol. 215:403-410

21. Silverman MP, Lundgren DG (1959) Studies on the chemoautotrophic iron bacterium Ferrobacillus ferrooxidans. II. Manomeric studies. J Bacteriol 77(3): 326-331

22. Liu JY, Xiu XX, Cai P (2009) Study of formation of jarosite mediated by Thiobacillus ferrooxidans in 9K medium. Procedia Earth Planet Sci. 1:706-712

23. Liu JS, Li BM, Zhong DY, Xia LX (2007) Preparation of jarosite by Acidithiobacillus ferrooxidans oxidation. J Cent South Univ T. 14:623-628

24. Kappler A, Schink B, Newman DK (2005) Fe(III) mineral formation and cell encrustation by the nitrate-dependent Fe(II)-oxidizer strain BoFeN1. Geobiology 3(4):235-245

25. Daoud J, Karamanev D (2006) Formation of jarosite during $\mathrm{Fe}^{2+}$ oxidation by Acidithiobacillus ferrooxidans. Miner Eng. 19:960-967

26. Adamou A, Manos G, Messios N, Georgiou L, Xydas C, Varotsis C (2016) Probing the whole ore chalcopyrite-bacteria interactions and jarosite biosynthesis by Raman and FTIR microspectroscopies. Bioresource Technol 214:852-855

27. Sivendra R, Lo HS, Lim KT (1975) Identification of Chromobacterium violaceum: pigmented and non-pigmented strains. Microbiology. 90:21-31

28. De la Iglesia R, Castro D, Ginocchio R, Van Der Lelie D, Gonza B (2006) Factors influencing the composition of bacterial communities found at abandoned copper-tailings dumps. J Appl Microbiol. 500:537-544

29. Mendez MO, Neilson JW, Maier RM (2008) Characterization of a bacterial community in an abandoned semiarid lead-zinc mine tailing Site. Appl Environ Microbiol. 74(12):3899-3907

30. Pages D, Rose J, Conrod S, Cuine S, Carrier P, Heulin T et al (2008) Heavy metal tolerance in Stenotrophomonas maltophilia. PLoS One. 3(2):e1539 
31. Vicentin RP, Valentim J, Regina C, Labory G (2018) Tolerance to and accumulation of cadmium, copper, and zinc by Cupriavidus necator. Rev Basileira Cienc do Solo 42:e0170080

32. Yang Y, Hu M, Zhou D, Fan W, Wang X, Huo M (2017) A novel copperresistant bacterium Cupriavidus gilardii CR3: characteristics and mechanisms. R Soc Chem 7:18793-18802

33. Liang Y, Mei JQCJ, Wang JJCQY, Yin GSWBY (2019) Characterization of Cu and $\mathrm{Cd}$ biosorption by Pseudomonas sp . strain DC-B3 isolated from metal mine soil. Int J Environ Sci Technol 16:4035-4046

34. Bensidhoum L, Tabli N, Kupferschmied P, Weiss A, Rothballer M, Schmid M et al (2016) Heavy metal tolerant Pseudomonas protegens growth promoting, insecticidal and antifungal activities. Eur J Soil Biol. 75:38-46

35. Xu S, Xing Y, Liu S, Huang Q, Chen W (2019) Role of novel bacterial Raoultella sp. strain X13 in plant growth promotion and cadmium bioremediation in soil. Appl Microbiol Biotechnol. 103(9):3887-3897

36. Sklodowska A, Mielnicki S, Drewniak L (2018) Raoultella sp. SM1, a novel iron-reducing and uranium-precipitating strain. Chemosphere. 195:722-726

37. Biswas R, Vivekanand V, Saha A, Ghosh A, Sarkar A (2019) Arsenite oxidation by a facultative chemolithotrophic Delftia spp. BAs29 for its potential application in groundwater arsenic bioremediation. Int Biodeterior Biodegrad 136:55-62

38. Funari R, Ripa R, Skoglund U, Shen AQ (2019) Detecting gold biomineralization by Delftia acidovorans biofilms on a quartz crystal microbalance. ACS Sens 4:3023-3033

39. Porcheron G, Garénaux A, Proulx J, Sabri M (2013) Iron, copper, zinc, and manganese transport and regulation in pathogenic Enterobacteria: correlations between strains, site of infection and the relative importance of the different metal transport systems for virulence. Front Cell Infect Microbiol. 3:90

40. Kruszewski M (2003) Labile iron pool: the main determinant of cellular response to oxidative stress. Mutat Res. 531:81-92

41. Ochoa-Herrera V, León G, Banihani Q, Field JA (2011) Toxicity of copper (II) ions to microorganisms in biological wastewater treatment systems. Sci Total Environ. 412:380-385

42. Sorokina EV, Yudina TP, Bubnov IA, Danilov VS (2013) Assessment of iron toxicity using a luminescent bacterial test with an Escherichia coli recombinant strain. Microbiology. 82:439-444

43. Mcdevitt CA, Ogunniyi AD, Valkov E, Lawrence MC, Kobe B, Mcewan AG et al (2011) A molecular mechanism for bacterial susceptibility to zinc. PLoS Pathog 7(11):e1002357

44. Davin-regli A, Pagès J (2015) Enterobacter aerogenes and Enterobacter cloacae; versatile bacterial pathogens confronting antibiotic treatment Front Microbiol. 6(392)

45. Patel CB, Shanker R, Gupta VK, Upadhyay RS, Sutherland M (2016) Q-PCR based culture-independent enumeration and detection of Enterobacter : an emerging environmental human pathogen in riverine systems and potable water. Front Microbiol. 7(172)

46. Taghavi S, Van Der Lelie D, Hoffman A, Zhang Y, Walla MD (2010) Genome sequence of the plant growth promoting endophytic bacterium Enterobacter sp.638. Plos Genet. 6(5):e1000943

47. Liu W, Chung M, Wong C, Jiang JW, Kin-Hi Hui R, Leung F (2012) Complete genome sequence of the endophytic Enterobacter cloacae. J Bacteriol. 194(21):5965

48. El-Deeb B (2009) Plasmid mediated tolerance and removal of heavy metals by Enterobacter sp. Am J Biochem Biotechnol. 5(1):47-53

49. Singh RP, Nalwaya S, Jha PN (2017) The draft genome sequence of the plant growth promoting rhizospheric bacterium Enterobacter cloacae SBP-8. Genomics Data. 12:81-83

50. Thul ST, Nigam B, Tiwari S, Pandey RA (2019) Arsenite-oxidation performance of microbes from abandoned iron ore mine. Indian J Biotechnol 18:34-41

51. Ashassi-Sorkhabi H, Moradi-Haghigi M, Zarrini G, Javaherdashti R (2012) Corrosion behavior of carbon steel in the presence of two novel ironoxidizing bacteria isolated from sewage treatment plants. Biodegradation. 23:69-79

52. Su JF, Cheng C, Huang T, Ma F, Lu JS, Shao SC (2016) Characterization of coupling autotrophic denitrification with iron cycle bacterium Enterobacter sp. CC76 and its application of groundwater. J Taiwan Inst Chem Eng. 66: $106-114$
53. Liu H, Wang H. (2016) Characterization of Fe (III)-reducing enrichment culture and isolation of Fe (III)-reducing bacterium Enterobacter sp. L6 from marine sediment. J Biosci Bioeng. xx(xx):10-4.

54. Hedrich S, Schlömann M, Johnson DB (2011) The iron-oxidizing proteobacteria. Microbiology. 157:1551-1564

55. Valdés J, Pedroso I, Quatrini R, Dodson RJ, Tettelin H, li RB et al (2008) Acidithiobacillus ferrooxidans metabolism : from genome sequence to industrial applications. BMC Genomics 24:1-24

56. Bacelar-Nicolau P, Johnson DB (1999) Leaching of pyrite by acidophilic heterotrophic iron-oxidizing bacteria in pure and mixed cultures. Appl Environ Microbiol. 65:585-590

\section{Publisher's Note}

Springer Nature remains neutral with regard to jurisdictional claims in published maps and institutional affiliations.

\section{Submit your manuscript to a SpringerOpen ${ }^{\circ}$ journal and benefit from:}

- Convenient online submission

- Rigorous peer review

- Open access: articles freely available online

- High visibility within the field

- Retaining the copyright to your article

Submit your next manuscript at $>$ springeropen.com 